\title{
Nitrogen conservation in soil and crop residues as affected by crop rotation and soil disturbance under Mediterranean conditions
}

\author{
A. de Varennes $\cdot$ M. O. Torres $\cdot$ C. Cunha-Queda \\ M. J. Goss • C. Carranca
}

Received: 24 July 2006 /Revised: 19 January 2007 / Accepted: 25 January 2007 / Published online: 24 February 2007

(C) Springer-Verlag 2007

\begin{abstract}
We investigated conservation and cycling of $\mathrm{N}$ under oat-oat and lupine-oat rotations in disturbed and undisturbed soil, when roots or roots plus aboveground residues were retained. Crop residues were labelled with ${ }^{15} \mathrm{~N}$ in Year 1, and differential soil disturbance was imposed after harvest. In Year 2, plant growth, $\mathrm{N}$ transfer from residue into the various sinks of the second crop (plant, soil, and residual residues), and changes in microbial activity and numbers were determined. Oat biomass was greater after lupine than after oat due to differences in supply of $\mathrm{N}$ from these residues. Buried residues of both crops appeared to decompose faster than when left on the soil surface. Lupine residues decomposed faster than oat residues. Oat biomass was not affected by soil disturbance if grown after lupine but decreased when oat straw was buried in the soil. More residue $\mathrm{N}$ was recovered from soil than from the crop. Most ${ }^{15} \mathrm{~N}$ was recovered from disturbed soil, which also had greater dehydrogenase activity and more culturable fungi. At the end of the oat-oat rotation, 20 and $5 \mathrm{~kg} \mathrm{~N} \mathrm{ha}^{-1}$ were derived from the roots of the first crop in undisturbed or
\end{abstract}

\footnotetext{
A. de Varennes $(\varangle) \cdot$ M. O. Torres $\cdot$ C. Cunha-Queda Department of Agricultural and Environmental Chemistry, Instituto Superior de Agronomia, TULISBON, Tapada da Ajuda, 1349-017 Lisbon, Portugal

e-mail: adevarennes@isa.utl.pt

M. J. Goss

Kemptville Campus, University of Guelph,

P.O. Box 2003, 830 Prescott St.,

Kemptville, ON K0G 1J0, Canada

C. Carranca

National Agronomic Station,

Avenida de República,

2784-505 Oeiras, Portugal
}

disturbed soil, respectively. Equivalent values for the lupineoat rotation were 18 and $44 \mathrm{~kg} \mathrm{~N} \mathrm{ha}^{-1}$. Returning aboveground residues provided an extra $52-80 \mathrm{~kg} \mathrm{~N} \mathrm{ha}^{-1}$ for oat and $61-63 \mathrm{~kg} \mathrm{~N} \mathrm{ha}^{-1}$ for lupine relative to treatments where they were removed. Over a year, lupine contributed 9 to $20 \mathrm{~kg} \mathrm{~N} \mathrm{ha}^{-1}$ more to the agroecosystem than did oat.

Keywords Crop residues - Legumes $\cdot \mathrm{N}$ conservation . Lupine $\cdot$ Oat $\cdot$ Soil disturbance

\section{Introduction}

The climate in the Mediterranean regions of Southern Europe is characterized by hot and dry summers and mild winters. The rainy season usually starts in October and finishes in May-June; hence, under rainfed conditions, only one crop can be grown per year, and the extended dry period over a part of the spring and during summer results in a fallow period of several months. Soils in the region are often shallow, limited in organic matter content, and susceptible to water and wind erosion.

The continuous cultivation of cereals (albeit with some weather-enforced fallow periods) is the traditional cropping system on the plains of the Iberian Peninsula (López et al. 2005), but rotations including grain legumes have also been used since antiquity because of their beneficial effects on following non-legume crops. There is an extensive body of literature that addresses the benefits of legumes in crop rotations in many countries (Heenan 1995; Kumar and Goh 2002; Shah et al. 2003; Mayer et al. 2003; Jensen et al. 2004). Lupines grow well in sandy to sandy loam soils in semi-arid climates. They form a very efficient symbiosis with rhizobia and can derive up to $93 \%$ of its $\mathrm{N}$ from the atmosphere (Unkovich et al. 1995). 
Surface placement of crop residues can protect the soil from the destructive forces of wind and water erosion, and long-term studies have shown an influence of no-till and residue conservation practices on the preservation of soil organic matter (Heenan et al. 2004; Diekow et al. 2005). In contrast, residue incorporation by tillage increases the accessibility of organic materials for soil organisms and can lead to a more rapid $\mathrm{N}$ cycling.

The effect of tillage on soil microbial populations have generally been studied by comparing microbial numbers, enzyme activity (in particular dehydrogenase as a general measure of microbial activity), and microbial biomass (Jimenez et al. 2002; Gil-Sotres et al. 2005).

Few studies have compared the effect of legumes and cereal residues in relation to soil disturbance (Bayer et al. 2000; Kumar and Goh 2002; Heenan et al. 2004). The separate contribution of roots and aboveground tissues have been addressed rarely, while in some cases, roots have been included in a rhizodeposition term (Unkovich et al. 1995; Mayer et al. 2003).

The use of ${ }^{15} \mathrm{~N}$ labelled residues allows for the detection of applied $\mathrm{N}$ in various sinks including the plant, soil, and residual residues. In most of the experiments using ${ }^{15} \mathrm{~N}$ labelled residues, they were incorporated in the soil, and surface placement was not considered (Jensen 1997; Kramer et al. 2002; Mayer et al. 2003). Such information is required to understand the role of crop residues in nutrient conservation and cycling in agroecosystems.

The objectives of the present study were (1) to compare the effect of a legume and a cereal in a subsequent crop as related to surface application of crop residues vs incorporation into the soil; (2) to compare the effect of these rotations on microbial numbers and activity; (3) to determine the conservation of residue $\mathrm{N}$ in the soil-plant system; (4) to determine the additional benefit derived from the conservation of aboveground residues in the soil.

\section{Materials and methods}

The experiment took place in Pegões Experimental Station, Portugal $\left(38^{\circ} 24^{\prime} \mathrm{N}, 8^{\circ} 35^{\prime} \mathrm{W}\right)$. The climate is typically Mediterranean with dry hot summers and mild winters. Average minimum temperatures during the experimental period ranged from $1.9^{\circ} \mathrm{C}$ in February to $15.5^{\circ} \mathrm{C}$ in August and maximum temperatures from $15.4^{\circ} \mathrm{C}$ in December to $32.5^{\circ} \mathrm{C}$ in August. Total precipitation from October 2004 to June 2005 was $240 \mathrm{~mm}$. An additional $100 \mathrm{~mm}$ of water had to be provided in January and February 2005 because there was no rain over this period.

In Year 1, the objective was to produce crop residues labelled with ${ }^{15} \mathrm{~N}$ for use in Year 2 and to introduce a differential disturbance in the soil thereby simulating tilled vs no-till conditions.

The sandy soil (Haplic Podzol) had the following characteristics $(0-30 \mathrm{~cm}$ layer): $\mathrm{pH}$ in water $(1: 25) 6.0$, $7.5 \mathrm{~g} \mathrm{~kg}^{-1}$ organic $\mathrm{C}$ content, $0.57 \mathrm{~g} \mathrm{~kg}^{-1}$ Kjeldahl-N content, and $6 \mathrm{mg} \mathrm{kg}^{-1} \mathrm{NO}_{3}-\mathrm{N}$. Twenty-four cylinders ( $h=15 \mathrm{~cm}, \varphi=15 \mathrm{~cm}$ ) were filled with $3.5 \mathrm{~kg}$ of soil that received a NPK basal dressing. Nitrogen $\left(100 \mathrm{mg} \mathrm{N} \mathrm{kg}^{-1}\right.$ of soil) was supplied as ammonium sulfate doubly enriched with $10 \%{ }^{15} \mathrm{~N}$ to label the plant tissues.

Half of the cylinders were sown with oat (Avena sativa L. cv Sta Eulália), and plant number was adjusted to nine per cylinder. The remaining cylinders were sown with lupine (Lupinus albus L. cv Estoril), and plant number adjusted to four per cylinder. These plant densities are equivalent to about 400 and 175 plants $\mathrm{m}^{-2}$, respectively, and correspond to typical densities used in the field.

In the field, the cylinders were kept in an outdoor area protected with a net and moved to a covered area when it rained. The cylinders were supplied with deionized water to maintain $70 \%$ of the water-holding capacity of the soil.

All the material that was shed from lupines was kept (leaves, flowers, and aborted pods) and added to the harvested material. The oat and lupine plants were harvested at physiological maturity in June 2004 and separated into straw and seeds. The plant material was washed with deionized water, dried at $65^{\circ} \mathrm{C}$, and weighed. Subsamples of straw from both crops were ground for analysis. Nitrogen was determined by the Kjeldahl method, the ${ }^{15} \mathrm{~N}$ enrichment by mass spectrometry, and the $\mathrm{C}$ concentration by Dumas combustion, according to standardized procedures (AOAC 1990). The lignin content was determined as the insoluble fraction after digestion for 25 min with a mixture of nitric $(6 \%)$ and acetic $(73 \%)$ acids.

Biological $\mathrm{N}_{2}$ fixation in lupine was determined according to Rennie and Dubetz (1986):

$$
\% \mathrm{Nda}=100 \times\left(1-\frac{\%{ }^{15} \mathrm{~N} \text { atom } \text { excess }_{\text {fixing plant }}}{\%^{15} \mathrm{~N} \text { atom excess }} \text { non-fixing plant }\right)
$$

where $\% \mathrm{Nda}$ is the percentage of $\mathrm{N}$ derived from atmosphere. Oat was used as the non-fixing reference plant, and $\%{ }^{15} \mathrm{~N}$ atom excess was calculated using the natural abundance of ${ }^{15} \mathrm{~N}$ in air $(0.3663 \%)$ as reference.

After harvest, the cylinders received 1.21 of deionized water to leach $\mathrm{NO}_{3}-\mathrm{N}$ and left to dry. The soil from half of the cylinders was removed and passed through a $5-\mathrm{mm}$ sieve to simulate tillage. This approach has been used before (Goss and de Varennes 2002). A small soil sample was taken from each of these cylinders for analysis. The root material separated on the sieve was cut into 2 - to $3-\mathrm{cm}$ long segments. Small samples of root material were taken 
in triplicate for analysis of ${ }^{15} \mathrm{~N}$ enrichment. In half of these cylinders, the roots were mixed with the soil and the mixture repacked into the cylinders to the same bulk density. In the other half of the cylinders, the soil was mixed with the roots and the aboveground residues of each crop (20.9 $\mathrm{g}$ of oat straw per cylinder or $4.8 \mathrm{~g}$ of empty pods and $10.7 \mathrm{~g}$ of lupine shoots per cylinder), which were also cut into 2- to $3-\mathrm{cm}$ long segments.

Half of the cylinders with undisturbed soil received the same amount of crop residues, which were distributed over the soil surface. The other half received no aboveground residues. As a result, eight different treatments with three replicates each were obtained: two types of residues (oat or lupine) $\times$ two types of soil disturbance (disturbed or undisturbed) $\times$ two amounts of residues (roots only or roots plus aboveground residues).

The cylinders received no water during the summer and were buried in a complete randomized design in October 2004 when the first rains were expected. The cylinders received a nutrient solution that supplied $5 \mathrm{mg} \mathrm{P}, 9 \mathrm{mg} \mathrm{K}$, $5 \mathrm{mg} \mathrm{Mg}$, and $10 \mathrm{mg} \mathrm{N} \mathrm{kg}^{-1}$ of soil as calcium dihydrogen phosphate, potassium sulfate, magnesium sulfate, and ammonium sulfate, respectively, according to the fertilizer recommendation for this crop (LQARS 2000). All cylinders were sown with oat (A. sativa L. cv Sta Eulália), and plant number was adjusted to nine per cylinder 3 weeks later.

Two topdressings with $10 \mathrm{mg} \mathrm{N} \mathrm{kg}{ }^{-1}$ of soil were applied in February and March 2005. In total, each cylinder received $\mathrm{N}$ equivalent to about $60 \mathrm{~kg} \mathrm{~N} \mathrm{ha}{ }^{-1}$, the recommended rate for winter oat in the region (LQARS 2000).

Harvest took place at physiological maturity in May 2005. Shoots were collected and seeds separated. The plant residues that were still visible on the soil surface were removed from each cylinder. The soil was removed from the cylinders, the roots collected, and the soil passed through a $2-\mathrm{mm}$ sieve. Lupine or oat residues that were retained on the sieve were collected. All plant material and residual residues were washed with deionized water, dried at $65^{\circ} \mathrm{C}$, and weighed.

The plant material and residual residues were ground for analysis of $\mathrm{N}$ concentration by the Kjeldahl method and for the ${ }^{15} \mathrm{~N}$ enrichment by mass spectrometry as before. Soil was analyzed for dehydrogenase activity according to Tabatabai (1994), for N concentration by the Kjeldahl method (Bremner 1996) and for the ${ }^{15} \mathrm{~N}$ enrichment by mass spectrometry. Culturable bacteria, fungi, and actinomycetes were enumerated according to Pochon and Tardieux (1962), with incubation periods of $24 \mathrm{~h}$ at $27^{\circ} \mathrm{C}$ for bacteria and 7 days at $27^{\circ} \mathrm{C}$ for fungi and actinomycetes. $\mathrm{NO}_{3}-$ was extracted with $2 \mathrm{M} \mathrm{KCl}$. Total $\mathrm{N}-\mathrm{NO}_{3}$ was determined by $\mathrm{Cd}$ reduction with subsequent colorimetric detection of $\mathrm{NO}_{2}^{-}$, and the ${ }^{15} \mathrm{~N}$ in $\mathrm{N}-\mathrm{NO}_{3}$ by the diffusion method (Brooks et al. 1989) and mass spectrometry.

The $\%{ }^{15} \mathrm{~N}$ atom excess in oat, residue, or soil was calculated using the equation:

$\%{ }^{15} \mathrm{~N}$ atom excess $=\%{ }^{15} \mathrm{~N}-0.62$

The amount of $\mathrm{N}$ derived from residues $(\mathrm{Ndr})$ in oat or soil at the end of phase II was calculated according to the equation adapted from Sakonnakhon et al. (2005):

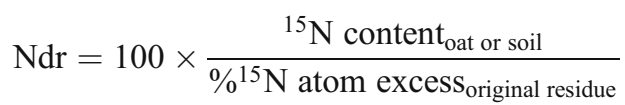

for all treatments, except when oat straw was conserved (because the $\%{ }^{15} \mathrm{~N}$ in oat straw was significantly different from that of roots). In this case, Eq. 3 was also used to calculate $\mathrm{Ndr}$ from straw, but the ${ }^{15} \mathrm{~N}$ content in plant or soil corresponded to the difference between equivalent treatments $\left({ }^{15} \mathrm{~N}\right.$ content in treatment with roots plus straw $-{ }^{15} \mathrm{~N}$ content in treatment with roots only). The Ndr was then calculated as:

$\mathrm{Ndr}=\mathrm{Ndr}_{\text {roots }}+\mathrm{Ndr}_{\text {straw }}$

In all cases, the ${ }^{15} \mathrm{~N}$ content was calculated as the product of total $\mathrm{N}$ content and the $\%{ }^{15} \mathrm{~N}$ atom excess in oat or soil.

The Ndr in residual residues was calculated as:

$\mathrm{Ndr}=$ Total $\mathrm{N}_{\text {residual residue }}$

$$
\times \frac{\%{ }^{15} \mathrm{~N} \text { atom excess }}{\text { residual residue }}
$$

The identification of the main associations in the measured data was done by principal component analysis (PCA) using the treatments as supplementary variables. Data kept in the final analysis had at least one correlation coefficient greater than 0.6.

Data were also analyzed for variance by the general linear model (GLM), and mean separation was performed using the Newman-Keuls's test with $p \leq 0.05$. Linear correlations between dehydrogenase activity and numbers of culturable microbes were tested.

\section{Results}

Year 1 - production of crop residues labelled with ${ }^{15} \mathrm{~N}$

Grain yield at the end of Year 1 was equivalent to 2.8 and $5.5 \mathrm{Mg} \mathrm{ha}^{-1}$ for lupine and oat, respectively. The yield of lupine was close to normal for the region while that of oat was greater than commonly achieved under field conditions (up to $4 \mathrm{Mg} \mathrm{ha}^{-1}$ ), presumably because of the more regular supply of water. 
Biomass of aboveground residues was $20.9 \mathrm{~g}$ per cylinder for oat and $15.5 \mathrm{~g}$ per cylinder for lupine $(4.8 \mathrm{~g}$ of empty pods plus $10.7 \mathrm{~g}$ of the remaining aboveground tissue; Table 1). The oat straw had greater $\mathrm{C}$ concentration but smaller $\mathrm{N}$ concentration than did the lupine residue, resulting in a $\mathrm{C} / \mathrm{N}$ ratio of 59 for oat and 32 for lupine. Consequently, as oat straw had more lignin than lupine, a greater mineralization rate would be expected for lupine residues than oat.

Both types of residues were labelled with sufficient ${ }^{15} \mathrm{~N}$ to follow the fate of $\mathrm{N}$ during Year 2 of the experiment. Although the lupine crop was not inoculated with rhizobia, and $100 \mathrm{~kg} \mathrm{~N} \mathrm{ha}^{-1}$ was applied to the soil, biological $\mathrm{N}_{2}$ fixation still took place, as indicated by the ${ }^{15} \mathrm{~N}$ enrichment being smaller in lupine than in oat material. The $\% \mathrm{Nda}$ estimated using Eq. 1 was about $30 \%$.

The aboveground residue applied in some of the treatments provided $157 \mathrm{mg}$ of total $\mathrm{N}$ and $11.5 \mathrm{mg}$ of ${ }^{15} \mathrm{~N}$ per cylinder for oat and $203 \mathrm{mg}$ of total $\mathrm{N}$ and $10.8 \mathrm{mg}$ of ${ }^{15} \mathrm{~N}$ for lupine.

The biomass of roots was not estimated. The ${ }^{15} \mathrm{~N}$ enrichment was $6.1 \%$ for oat roots and $5.4 \%$ for lupine roots. The latter value was not significantly different from that obtained for lupine straw.

At the end of Year 1, the Kjeldahl-N in the soil had increased from 0.57 to $0.68 \mathrm{~g} \mathrm{~kg}^{-1}$. The ${ }^{15} \mathrm{~N}$ enrichment was $0.62 \%$, with no significant difference between treatments. To discriminate between ${ }^{15} \mathrm{~N}$ derived from the soil pool and ${ }^{15} \mathrm{~N}$ derived from crop residues, the $\%{ }^{15} \mathrm{~N}$ atom excess in plant, residues, and soil of Year 2 was determined according to Eq. 2.

Year 2-biomass and $\mathrm{N}$ in oat and soil

Yield of oat grain at the end of Year 2 varied from 1.3 to 3.0 $\mathrm{Mg} \mathrm{ha}^{-1}$ depending on treatment. The largest value was similar to the expected yield for this crop [2.5 Mg ha ${ }^{-1}$ according to LQARS (2000)] so that the results could be considered representative for field-grown winter oat.

Table 1 Biomass and characteristics of crop residues produced in Year 1

\begin{tabular}{lll}
\hline & \multicolumn{2}{l}{ Species } \\
\cline { 2 - 3 } & Oat & Lupine \\
\hline Biomass (g per cylinder) & $20.9 \mathrm{a}$ & $15.5 \mathrm{~b}$ \\
$\mathrm{C}\left(\mathrm{g} \mathrm{kg}^{-1}\right)$ & $445 \mathrm{a}$ & $424 \mathrm{~b}$ \\
$\mathrm{~N}\left(\mathrm{~g} \mathrm{~kg}^{-1}\right)$ & $7.5 \mathrm{~b}$ & $13.1 \mathrm{a}$ \\
$\%{ }^{15} \mathrm{~N}$ & $7.35 \mathrm{a}$ & $5.31 \mathrm{~b}$ \\
Lignin $(\%)$ & $39 \mathrm{a}$ & $32 \mathrm{~b}$ \\
\hline
\end{tabular}

Means in a row followed by the same letter are not significantly different as judged by the Newman-Keul's test at a level of 0.05 .
Two main associations between measured data and treatments were detected by PCA (Fig. 1). There was a strong association between the amount of residue (roots only or roots + straw) and the $\%{ }^{15} \mathrm{~N}$ atom excess in oat straw, soil, or soil $\mathrm{NO}_{3}-\mathrm{N}$ at the end of Year 2. As would be expected, the retention of aboveground residues led to greater values of $\%{ }^{15} \mathrm{~N}$ atom excess than when only roots remained in the soil (Tables 2 and 3), as they provided additional ${ }^{15} \mathrm{~N}$.

The second association detected by PCA was a strong positive relationship between dry matter of oat produced during phase II and the crop (either lupine or oat) grown during phase I (Fig. 1). In fact, oat dry matter was significantly greater when it followed lupine than in the oat-oat rotation (Table 2).

Soil disturbance had a low loading when the two first principal components were analyzed (Fig. 1), and therefore, its associations could only be studied by PCA using the third and fourth principal components (not shown). Analysis with the GLM and mean comparison showed that soil disturbance affected biomass of oat, soil microbial biomass, and $\%{ }^{15} \mathrm{~N}$ atom excess in soil, particularly when aboveground residues were retained. Yield of oat was reduced when oat straw was buried in the soil compared with surface placement, while soil disturbance had no effect on yield in the lupine-oat rotation (Table 2).

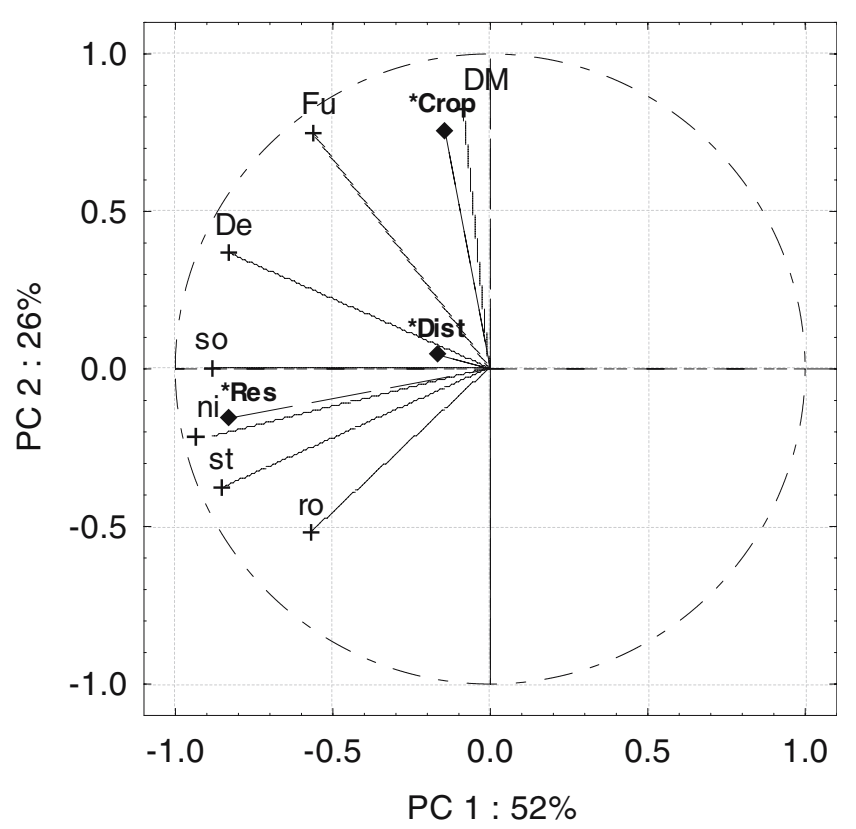

Fig. 1 Principal component analysis (PCA) of the main associations between measured data and treatments. st $\%{ }^{15} \mathrm{~N}$ atom excess in straw; ro $\%{ }^{15} \mathrm{~N}$ atom excess in roots; so $\%{ }^{15} \mathrm{~N}$ atom excess in soil; $n i \%{ }^{15} \mathrm{~N}$ atom excess in soil nitrate; $D M$ dry matter of oat from Year 2; De dehydrogenase activity in soil; $F u$ fungal number; Res aboveground residue plus roots vs roots only; Crop lupine vs oat in Year 1; Dist disturbed vs undisturbed soil 
Table 2 Biomass and characteristics of oat produced in Year 2

\begin{tabular}{|c|c|c|c|c|c|c|}
\hline \multirow[t]{2}{*}{ Treatment } & \multicolumn{3}{|l|}{ Straw } & \multicolumn{3}{|l|}{ Root } \\
\hline & $\begin{array}{l}\text { Biomass } \\
\text { (g per cylinder) }\end{array}$ & $\begin{array}{l}\text { Total N } \\
\left(\mathrm{g} \mathrm{kg}^{-1}\right)\end{array}$ & $\begin{array}{l}\%{ }^{15} \mathrm{~N} \text { atom } \\
\text { excess }\end{array}$ & $\begin{array}{l}\text { Biomass } \\
\text { (g per cylinder) }\end{array}$ & $\begin{array}{l}\text { Total N } \\
\left(\mathrm{g} \mathrm{kg}^{-1}\right)\end{array}$ & $\begin{array}{l}\%{ }^{15} \mathrm{~N} \text { atom } \\
\text { excess }\end{array}$ \\
\hline \multicolumn{7}{|l|}{ Oat } \\
\hline$+\mathrm{D}+\mathrm{S}$ & $4.7 \mathrm{c}$ & $9.7 \mathrm{a}$ & $0.77 \mathrm{a}$ & $3.6 \mathrm{c}$ & $10.0 \mathrm{a}$ & $1.92 \mathrm{a}$ \\
\hline$+\mathrm{D}-\mathrm{S}$ & $8.2 \mathrm{~b}$ & $6.7 \mathrm{~b}$ & $0.04 \mathrm{~d}$ & $4.5 \mathrm{bc}$ & $7.6 \mathrm{c}$ & $0.81 \mathrm{bc}$ \\
\hline$-\mathrm{D}+\mathrm{S}$ & $8.8 \mathrm{~b}$ & $7.1 \mathrm{ab}$ & $0.31 \mathrm{bc}$ & $8.7 \mathrm{ab}$ & $7.6 \mathrm{c}$ & $1.99 \mathrm{a}$ \\
\hline$-\mathrm{D}-\mathrm{S}$ & $9.2 \mathrm{~b}$ & $8.1 \mathrm{ab}$ & $0.10 \mathrm{~d}$ & $6.6 \mathrm{ab}$ & $9.3 \mathrm{ab}$ & $1.54 \mathrm{a}$ \\
\hline \multicolumn{7}{|l|}{ Lupine } \\
\hline$+\mathrm{D}+\mathrm{S}$ & $13.2 \mathrm{a}$ & $7.7 \mathrm{ab}$ & $0.44 \mathrm{~b}$ & $9.5 \mathrm{a}$ & $7.8 \mathrm{bc}$ & $1.25 \mathrm{ab}$ \\
\hline$+\mathrm{D}-\mathrm{S}$ & $10.3 \mathrm{a}$ & $6.3 \mathrm{~b}$ & $0.06 \mathrm{~d}$ & $6.3 \mathrm{bc}$ & $6.9 \mathrm{c}$ & $0.52 \mathrm{c}$ \\
\hline$-\mathrm{D}+\mathrm{S}$ & $12.8 \mathrm{a}$ & $7.4 \mathrm{ab}$ & $0.37 \mathrm{~b}$ & $8.1 \mathrm{ab}$ & $8.3 \mathrm{bc}$ & $1.53 \mathrm{a}$ \\
\hline$-\mathrm{D}-\mathrm{S}$ & $13.6 \mathrm{a}$ & $6.0 \mathrm{~b}$ & $0.16 \mathrm{~cd}$ & $7.7 \mathrm{ab}$ & $7.9 \mathrm{bc}$ & $1.36 \mathrm{ab}$ \\
\hline
\end{tabular}

Means in a column followed by the same letter are not significantly different as judged by the Newman-Keul's test at a level of 0.05 .

(Positive D) disturbed soil; (negative D) undisturbed soil; (positive $S$ ) straw plus roots; (negative $S$ ) roots only

Dehydrogenase activity, number of culturable fungi, and $\%{ }^{15} \mathrm{~N}$ atom excess in the soil were greater when the soil was disturbed and straw of oat or lupine buried than when the soil and straw placed on the soil surface were left undisturbed (Table 3). Lupine residues supported a greater number of fungi than oat, in particular when straw was retained (Table 3). The removal of straw from the field resulted in less dehydrogenase activity and number of culturable fungi, at least in disturbed soil.

The number of culturable bacteria and actinomycetes (data not shown), total $\mathrm{N}$ concentration, and $\mathrm{NO}_{3}-\mathrm{N}$ were not affected by any of the treatments (Table 3).

Year $2-\mathrm{N}$ conservation in residues and soil

Lupine straw apparently decomposed faster than oat straw, so that at the end of Year 2, 21\% of the oat straw buried in the soil was still recognizable and was retained by the
2 -mm sieve, whereas only $14 \%$ of lupine straw could be separated from the soil after the second crop. More residues from both crops were still recognizable at the end of the experiment when the soil was not disturbed between Years 1 and 2 than when it was disturbed (Table 4). The values in undisturbed soil were $36 \%$ and $21 \%$ of the original residue for oat and lupine, respectively.

The $\mathrm{N}$ concentration in the residual residues was greater at the end of Year2 (with the exception of treatment $+\mathrm{D}+\mathrm{S}$ in Table 4); that is, the mass loss was greater than the $\mathrm{N}$ loss, but the $\%{ }^{15} \mathrm{~N}$ was smaller than at the beginning of phase II, suggesting a substitution of ${ }^{15} \mathrm{~N}$ labelled for unlabelled $\mathrm{N}$ in the residues.

Total $\mathrm{N}$ conserved in the soil or in the soil-plant system at the end of Year 2 was not significantly different between treatments (Table 5). Differences between treatments became apparent when the total amount of Ndr from Year 1 was considered-more Ndr was present in the soil or

Table 3 Dehydrogenase activity, fungi, and $\mathrm{N}$ in the soil at the end of Year 2

\begin{tabular}{|c|c|c|c|c|c|c|}
\hline Treatment & $\begin{array}{l}\text { Dehydrogenase } \\
\left(\mathrm{mg} \mathrm{TPF} \mathrm{g}^{-1}\right. \\
\left.16 \mathrm{~h}^{-1}\right)\end{array}$ & $\begin{array}{l}\text { Fungi } \\
(\mathrm{CFU} \times \\
\left.10^{4} \mathrm{~g}^{-1}\right)\end{array}$ & $\begin{array}{l}\text { Total N } \\
\left(\mathrm{g} \mathrm{kg}^{-1}\right)\end{array}$ & $\begin{array}{l}\%{ }^{15} \mathrm{~N} \text { atom } \\
\text { excess }\end{array}$ & $\begin{array}{l}\mathrm{N}-\mathrm{NO}_{3}- \\
\left(\mathrm{mg} \mathrm{kg}^{-1}\right)\end{array}$ & $\begin{array}{l}\%{ }^{15} \mathrm{~N}-\mathrm{NO}_{3}- \\
\text { atom excess }\end{array}$ \\
\hline \multicolumn{7}{|l|}{ Oat } \\
\hline$+\mathrm{D}+\mathrm{S}$ & $10.4 \mathrm{~b}$ & $45 \mathrm{~b}$ & $0.56 \mathrm{a}$ & $0.36 \mathrm{a}$ & $9.3 \mathrm{a}$ & $1.24 \mathrm{a}$ \\
\hline$+\mathrm{D}-\mathrm{S}$ & $7.4 \mathrm{c}$ & $20 \mathrm{~d}$ & $0.54 \mathrm{a}$ & $0.01 \mathrm{~d}$ & $10.7 \mathrm{a}$ & $0.52 \mathrm{~b}$ \\
\hline$-D+S$ & $8.2 \mathrm{c}$ & $32 \mathrm{c}$ & $0.56 \mathrm{a}$ & $0.12 \mathrm{c}$ & $12.3 \mathrm{a}$ & $1.10 \mathrm{a}$ \\
\hline$-\mathrm{D}-\mathrm{S}$ & $8.2 \mathrm{c}$ & $47 b$ & $0.52 \mathrm{a}$ & $0.06 \mathrm{~d}$ & $12.0 \mathrm{a}$ & $0.69 \mathrm{~b}$ \\
\hline \multicolumn{7}{|l|}{ Lupine } \\
\hline$+\mathrm{D}+\mathrm{S}$ & $15.6 \mathrm{a}$ & $142 \mathrm{a}$ & $0.56 \mathrm{a}$ & $0.32 \mathrm{a}$ & $12.7 \mathrm{a}$ & $1.10 \mathrm{a}$ \\
\hline$+\mathrm{D}-\mathrm{S}$ & $7.3 \mathrm{c}$ & $71 \mathrm{~b}$ & $0.56 \mathrm{a}$ & $0.18 \mathrm{~b}$ & $9.0 \mathrm{a}$ & $0.67 \mathrm{~b}$ \\
\hline$-D+S$ & $10.3 \mathrm{~b}$ & $72 \mathrm{~b}$ & $0.55 \mathrm{a}$ & $0.21 \mathrm{~b}$ & $13.7 \mathrm{a}$ & $1.08 \mathrm{a}$ \\
\hline$-\mathrm{D}-\mathrm{S}$ & $7.5 \mathrm{c}$ & $75 \mathrm{~b}$ & $0.50 \mathrm{a}$ & $0.03 \mathrm{~d}$ & $11.3 \mathrm{a}$ & $0.61 \mathrm{~b}$ \\
\hline
\end{tabular}

Means in a column followed by the same letter are not significantly different as judged by the Newman-Keul's test at a level of 0.05 .

(Positive D) disturbed soil; (negative D) undisturbed soil; (positive $S$ ) straw plus roots; (negative $S$ ) roots only; CFU colony forming units 
Table 4 Biomass and $\mathrm{N}$ in residual residues of oat and lupine at the end of Year 2

\begin{tabular}{llll}
\hline Treatment & $\begin{array}{l}\text { Biomass } \\
(\text { g per cylinder })\end{array}$ & $\begin{array}{l}\text { Total N } \\
\left(\mathrm{g} \mathrm{kg}^{-1}\right)\end{array}$ & $\%{ }^{15} \mathrm{~N}$ \\
\hline $\begin{array}{lll}\text { Oat } \\
+\mathrm{D}+\mathrm{S}\end{array}$ & $4.4 \mathrm{~b}$ & $9.9 \mathrm{~b}$ & $4.69 \mathrm{~b}$ \\
$-\mathrm{D}+\mathrm{S}$ & $7.5 \mathrm{a}$ & $12.6 \mathrm{~b}$ & $5.23 \mathrm{a}$ \\
Lupine & & & \\
$+\mathrm{D}+\mathrm{S}$ & $2.2 \mathrm{~d}$ & $11.6 \mathrm{~b}$ & $4.42 \mathrm{~b}$ \\
$-\mathrm{D}+\mathrm{S}$ & $3.3 \mathrm{c}$ & $14.4 \mathrm{a}$ & $3.72 \mathrm{c}$ \\
\hline
\end{tabular}

Means in a column followed by the same letter are not significantly different as judged by the Newman-Keul's test at a level of 0.05 .

(Positive D) disturbed soil; (negative D) undisturbed soil; (positive $S$ ) straw plus roots

soil-plant system at the end of Year 2 when straw was retained in the soil than when only roots were present (Table 5).

Although there were no significant differences between $\mathrm{Ndr}$ in oat of equivalent treatments when either crop residue was used, lupine provided more N (21.1 mg per cylinder) than oat residues (12.1 mg per cylinder) when the averages from all treatments were compared $(p<0.05)$. The total $\mathrm{N}$ present in oat from disturbed soil with oat straw was also less than when the plant was grown with lupine straw (Table 5). Oat grown after lupine had a total amount of $146.4 \mathrm{mg} \mathrm{N}$ in the nine plants of each cylinder, compared with $109.3 \mathrm{mg} \mathrm{N}$ when grown after oat (average of all treatments, $p<0.05$ ).

Soil disturbance enhanced the amount of $\mathrm{N}$ derived from lupine residues that could be accounted for in the soil-plant system, whereas the effect was not so clear when oat residues were used, as most of the $\mathrm{N}$ from oat roots seems to have been lost as a result of soil disturbance (Table 5).

Year 2-balance of the extra $\mathrm{N}$ introduced via harvest residues

At the end of Year 1, application of lupine or oat straw, respectively, returned an extra 157 or $203 \mathrm{mg}$ of total $\mathrm{N}$ to the soil. The additional gain in $\mathrm{N}$ by the plant-soil system could be calculated by comparison with equivalent treatments where only roots were present. In the case of lupine residues, soil disturbance resulted in less of this extra $\mathrm{N}$ being present in the residual residue and more in the second crop, with a small change in the amount of $\mathrm{N}$ in the soil pool (Fig. 2). Almost half of this additional $\mathrm{N}$ was unaccounted for; that is, it was lost from the soil-plant system or exported in the grain.

The effect of soil disturbance on the fate of $\mathrm{N}$ from oat straw was very different to that from lupine residue. Soil disturbance resulted in most of the additional $\mathrm{N}$ from oat straw being conserved within the soil pool (65\%), with only $17 \%$ of the extra $\mathrm{N}$ being left unaccounted. Surface-applied oat residues resulted in a great loss of $\mathrm{N}$ from the system (42\%), although an equivalent amount was still retained in the remaining residue.

\section{Discussion}

Several studies have shown that legumes can increase the yield of a subsequent crop, in particular when no fertilizer $\mathrm{N}$ is applied (Heenan 1995; Kumar and Goh 2002; Shah et al. 2003; Mayer et al. 2003; Jensen et al. 2004). In the present experiment, oat biomass production was greater

Table 5 Total amounts of $\mathrm{N}$ and of $\mathrm{N}$ derived from residues at the end of Year 2

\begin{tabular}{|c|c|c|c|c|c|c|c|c|}
\hline \multirow[t]{3}{*}{ Treatment } & \multicolumn{4}{|c|}{$\mathrm{N}$ derived from residues } & \multicolumn{4}{|l|}{ Total N } \\
\hline & \multicolumn{8}{|c|}{ mg per cylinder } \\
\hline & Plant & Residual residue & Soil & Total & Plant & Residual residue & Soil & Total \\
\hline \multicolumn{9}{|l|}{ Oat } \\
\hline$+\mathrm{D}+\mathrm{S}$ & $17 \mathrm{a}$ & $27 \mathrm{~b}$ & $106 \mathrm{a}$ & $150 \mathrm{~b}$ & $81 \mathrm{~b}$ & $44 \mathrm{~b}$ & $1955 \mathrm{a}$ & $2080 \mathrm{a}$ \\
\hline$+\mathrm{D}-\mathrm{S}$ & $5 \mathrm{~b}$ & - & $4 \mathrm{e}$ & $9 \mathrm{e}$ & $90 \mathrm{~b}$ & - & $1874 \mathrm{a}$ & $1963 \mathrm{a}$ \\
\hline$-\mathrm{D}+\mathrm{S}$ & $25 \mathrm{a}$ & $66 \mathrm{a}$ & $37 \mathrm{c}$ & $128 \mathrm{~b}$ & $129 \mathrm{ab}$ & $96 \mathrm{a}$ & $1957 \mathrm{a}$ & $2182 \mathrm{a}$ \\
\hline$-\mathrm{D}-\mathrm{S}$ & $18 \mathrm{a}$ & - & $18 \mathrm{~d}$ & $36 \mathrm{~d}$ & $138 \mathrm{ab}$ & - & $1801 \mathrm{a}$ & $1939 \mathrm{a}$ \\
\hline \multicolumn{9}{|l|}{ Lupine } \\
\hline$+\mathrm{D}+\mathrm{S}$ & $30 \mathrm{a}$ & $21 \mathrm{c}$ & $134 \mathrm{a}$ & $185 \mathrm{a}$ & $175 \mathrm{a}$ & $25 \mathrm{c}$ & $1958 \mathrm{a}$ & $2158 \mathrm{a}$ \\
\hline$+\mathrm{D}-\mathrm{S}$ & $5 \mathrm{~b}$ & - & $73 \mathrm{~b}$ & $78 \mathrm{c}$ & $109 \mathrm{ab}$ & - & 1964 a & $2073 \mathrm{a}$ \\
\hline$-\mathrm{D}+\mathrm{S}$ & $29 \mathrm{a}$ & $30 \mathrm{~b}$ & $84 \mathrm{~b}$ & $143 \mathrm{~b}$ & $160 \mathrm{ab}$ & $46 \mathrm{~b}$ & $1913 \mathrm{a}$ & $2119 a$ \\
\hline$-\mathrm{D}-\mathrm{S}$ & $20 \mathrm{a}$ & - & $12 \mathrm{~d}$ & $32 \mathrm{~d}$ & $142 \mathrm{ab}$ & - & $1733 \mathrm{a}$ & $1875 \mathrm{a}$ \\
\hline
\end{tabular}

Means in a column followed by the same letter are not significantly different as judged by the Newman-Keul's test at a level of 0.05 .

(Positive D) disturbed soil; (negative D) undisturbed soil; (positive $S$ ) straw plus roots; (negative $S$ ) roots only 
Fig. 2 Balance of the extra $\mathrm{N}$ introduced in the soil by oat or lupine straw

\section{Oat/disturbed}

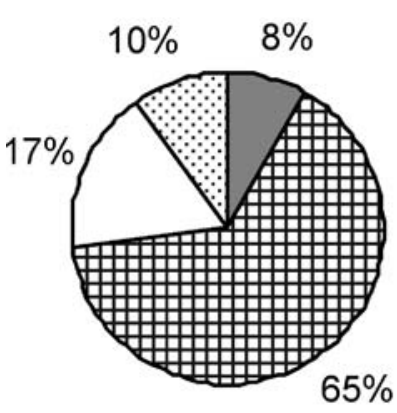

Lupine/disturbed

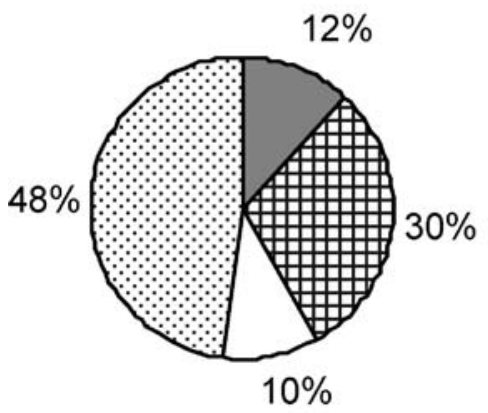

Oat/undisturbed

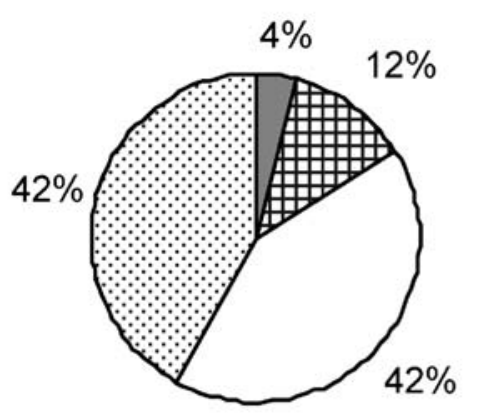

Lupine/undisturbed

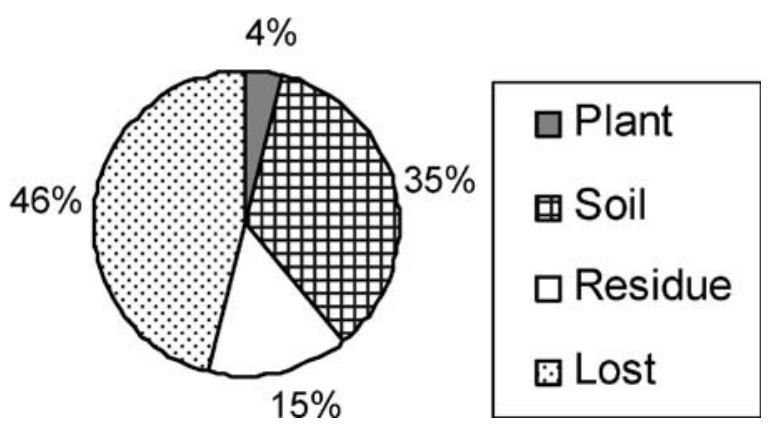

after lupine than after oat (Table 2), although $60 \mathrm{~kg} \mathrm{~N}$ ha $^{-1}$ was applied to the second crop in the rotation. This result contrasts with that of Jensen et al. (2004), where the growth of winter barley was similar after lupine, pea, or oat when barley received $\geq 60 \mathrm{~kg} \mathrm{~N}^{-1}$. However, these contrasting results may be due to different amounts of $\mathrm{N}$ being present in the soil pool in the two experiments (i.e., in our experiment the soil might be more N-limited), as these authors reported that lupine residues plowed into their sandy soil contributed about $15 \mathrm{~kg} \mathrm{~N} \mathrm{ha}^{-1}$ more than did oat residues.

Most of the beneficial effect of legumes to subsequent crops has been attributed to the supply of $\mathrm{N}$ through residues and via rhizodeposition (Unkovich et al. 1995). The average effect of lupine on oat growth (about 1.6 times that of oat biomass following oat in Year 1) could be explained by the supply of $\mathrm{N}$ through residues (about 1.7 times more $\mathrm{N}$ supplied by lupine residues compared with oat), although the average increase in the total $\mathrm{N}$ content of oat was only 1.3 times more after lupine compared with oat. This suggests that there was a greater substitution of soil and fertilizer $\mathrm{N}$ by residue $\mathrm{N}$ in the presence of lupine compared with oat.

The Ndr was calculated based on Eq. 2 to eliminate the contribution of ${ }^{15} \mathrm{~N}$ fertilizer and rhizodeposition during Year 1 to oat growth in Year 2, which would lead to an overestimation of the residue-derived $\mathrm{N}$ to the second crop in the rotation (Mayer et al. 2003). With this procedure, only the ${ }^{15} \mathrm{~N}$ enrichment in the soil-plant system over the soil background at the beginning of Year 2 was considered as being derived from crop residues. Moreover, the similar ${ }^{15} \mathrm{~N}$ enrichment in the soil at the end of Year 1 following either lupine or oat shows that the eventual differences in rhizodeposition between the two crops were not enough to lead to a significant difference in the ${ }^{15} \mathrm{~N}$ pool in the soil and was not the main explanation for the effect of lupine on oat growth.

Several factors control the rate of residue decomposition, with temperature, soil water content, and size, location and composition of residues being of prime importance. The $\mathrm{C} / \mathrm{N}$ ratio and the lignin content of residues give an indication of the rate of decomposition and whether mineralization or immobilization of $\mathrm{N}$ will prevail (Chaves et al. 2004). Lupine residues, with a smaller $\mathrm{C} / \mathrm{N}$ ratio and less lignin than oat, decomposed faster than oat residues, as expected from studies with other crops (Kumar and Goh 2002).

Several studies have compared surface placement vs incorporation of plant residues. In general, surface-applied residues decompose more slowly due to the smaller water content and decreased access of soil microbes (Kumar and Goh 2002; Corbeels et al. 2003). As a result, soil organic matter appears to increase with surface placement of crop residues compared with residue incorporation, especially in warmer climates (Doran 1987). The greater mass loss from buried lupine or oat residues compared with surface 
placement was consistent with results from other experiments (Franzluebbers et al. 1996; Sakonnakhon et al. 2005).

In summary, the differential effects of lupine vs oat on the subsequent crop $\mathrm{N}$ supply and of the surface placement vs incorporation on residue decomposition rate, as well as the apparent faster decomposition of legume residues compared with cereal, are consistent with results from previous published work suggesting that this experiment provides a model that can be used to compare with those dealing with other crops grown in different locations.

Soil disturbance, as it led to a faster decomposition of crop residues, could result in more $\mathrm{N}$ becoming available for plant uptake and lead to enhanced growth of the subsequent crop in the rotation. Alternatively, the incorporation of residues poor in $\mathrm{N}$ might result in yield depression due to N immobilization (Kumar and Goh 2002).

In the present experiment, oat biomass was not affected by soil disturbance when grown after lupine, both when harvest residues were conserved in the soil and when only roots were present (Table 2), which suggests that legume roots are a more important source of $\mathrm{N}$ to a subsequent crop than is straw.

The ${ }^{15} \mathrm{~N}$ atom excess and the $\mathrm{Ndr}$ in oat were also similar whether lupine straw was buried or surface applied; that is, soil disturbance had no effect on $\mathrm{N}$ recovery from lupine straw. This result contrasted with that of Sakonnakhon et al. (2005) who obtained a greater recovery by a following maize crop of ${ }^{15} \mathrm{~N}$ labelled groundnut residues buried in the soil than when they were surface applied. The fact that the presence of lupine straw led to increased $\mathrm{Ndr}$ in disturbed soil (Tables 5) suggests, as already stated, that a substitution of soil and fertilizer $\mathrm{N}$ by residue $\mathrm{N}$ took place. It is clear that the fate of straw residue needed to be further investigated.

In contrast to the effect of lupine residues just described, soil disturbance resulted in decreased growth of oat when straw was buried in the soil, as described previously for cereals (Kumar and Goh 2002), presumably due to $\mathrm{N}$ immobilization, allelochemicals, or toxic effects resulting from the decomposing oat straw.

More of the residue $\mathrm{N}$ was recovered in the soil than in the crop as described for other crop rotations (Mubarak et al. 2003; Sakonnakhon et al. 2005). Long-term studies have found increases in soil organic matter with crop residue returned to the soil (Bayer et al. 2000; Diekow et al. 2005). In the present case, there were no significant differences in the total amount of $\mathrm{N}$ of the soil at the end of the experiment, which was to be expected because the background pool of soil $\mathrm{N}$ was very large compared with the amount of $\mathrm{N}$ introduced by the residues. However, as the residues were labelled with ${ }^{15} \mathrm{~N}$, it was possible to follow the short-term changes in soil N. Lupine residues provided more N (76 mg per cylinder) than oat residues (41 $\mathrm{mg}$ per cylinder) to the soil when the averages from all treatments were compared $(p<0.05)$. Campbell et al. (1991) had already suggested that legumes, with smaller $\mathrm{C} / \mathrm{N}$ ratios, resulted in a more efficient conversion to stable soil organic matter than cereals.

The greatest isotopic recovery was observed in disturbed soil (Table 5), as described when groundnut residues were incorporated in the soil compared with surface placement (Sakonnakhon et al. 2005). This suggests that soil disturbance might have resulted in more ${ }^{15} \mathrm{~N}$ being retained by soil microorganisms rather than being taken up by plants.

The dehydrogenase activity is associated with living cells and has been used to measure microbial activity (Mahmood et al. 2005). Lupine straw sustained a greater dehydrogenase activity and number of culturable fungi than oat (Table 3), presumably because lupine tissues had more $\mathrm{N}$ and less lignin and decomposed faster $(21 \%$ of the oat residues incorporated into the soil were still recognizable at the end of phase II, whereas only $14 \%$ of lupine residues remained after the second crop).

The greatest enzymatic activities corresponded to treatments where straw (both from lupine and oat) was incorporated into the soil rather than being left on the soil surface (Table 3), presumably because this allowed a closer contact with soil microbes, and this can have a higher effect on microbial activity.

Culturable bacteria or actinomycetes were not affected by treatments, but the number of culturable fungi was also larger when straw was buried. In fact, the values for dehydrogenase activity and culturable fungi were linearly correlated $(r=0.71$, $p<0.005, n=24)$. Although culturable microbes represent a small percentage of total soil microorganisms, together these results support the hypothesis that a greater $\mathrm{N}$ immobilization took place as a result of soil disturbance.

To calculate the amount of $\mathrm{N}$ still present in harvest residue from Year 1, it was necessary to take into account the rate of mass loss of straw and the fact that this was greater than the rate of $\mathrm{N}$ loss. As a result, the concentration of total $\mathrm{N}$ increased (and the $\%{ }^{15} \mathrm{~N}$ decreased) in the residues still present in the soil at the end of Year 2. Incorporation of soil $\mathrm{N}$ (from soil, fertilizer, or mineralized residues) into lignin-like polymers could explain this increase (Franzluebbers et al. 1996). Because of this, the $\mathrm{N}$ recovery in residual residues could not be calculated based on the $\%{ }^{15} \mathrm{~N}$ in the residues but had to be estimated using Eq. 5. About 18 and $44 \%$ of $\mathrm{N}$ from initial oat straw were still present in residual residue at the end of the experiment in disturbed and undisturbed soil, respectively, while the $\mathrm{N}$ recovery from lupine residues was smaller (10 and $16 \%$ for each soil treatment, respectively).

Although oat in Year 2 received the recommended rate of $60 \mathrm{~kg} \mathrm{~N} \mathrm{ha}^{-1}$, residues of both crops still contributed to plant and soil N. At the end of the oat-oat rotation, the total amount of $\mathrm{N}$ derived from the residues of the first crop (straw plus roots) present in the soil-plant system amounted 
to $85 \mathrm{~kg} \mathrm{~N} \mathrm{ha}^{-1}$ when straw was buried and $72 \mathrm{~kg} \mathrm{~N} \mathrm{ha}^{-1}$ when it was applied on the soil surface. In the lupine-oat rotation, the equivalent values were 105 and $81 \mathrm{~kg} \mathrm{~N} \mathrm{ha}^{-1}$. As only a small percentage of these totals were taken up by the second crop in the rotation, the continuing conservation of harvest residues should contribute to a buildup of soil organic matter.

The potential $\mathrm{N}$ benefit from narrow leaf lupine in Australia (straw plus roots) reached $75 \mathrm{~kg} \mathrm{~N} \mathrm{ha}^{-1}$ (Unkovich et al. 1995), a calculation based on the balance of $\mathrm{N}_{2}$ fixed and $\mathrm{N}$ removed in grain. Because $\mathrm{N}$ losses were not considered, the actual benefit for the agroecosystem would be smaller than $75 \mathrm{~kg} \mathrm{~N} \mathrm{ha}^{-1}$. White lupine can derive about $90 \%$ of its $\mathrm{N}$ from atmosphere in Pegões (unpublished results) and can, therefore, contribute $73-95 \mathrm{~kg} \mathrm{~N} \mathrm{ha}^{-1}$ each year to the soilplant system if harvest residues are returned to the soil. This value is substantially greater than that reported by Unkovich et al. (1995) because it takes into account the $\mathrm{N}$ losses during the second crop in the rotation and the $\mathrm{N}$ effectively present in the soil-plant system.

As already mentioned, straw conservation did not lead to enhanced growth in the succeeding crop in the rotation, although it contributed decisively to an increase in the total amount of $\mathrm{N}$ from residues present in the plant-soil system (Table 5). When the fate of the additional $\mathrm{N}$ introduced via straw was analyzed, it became clear that, with the exception of the treatment where oat straw was buried, more than $40 \%$ of the extra $\mathrm{N}$ was unaccounted for at the end of the experiment (Fig. 2). A small percentage of this would be exported in the grain, but the vast majority was lost from the system.

The greatest apparent gain in $\mathrm{N}$ to the agroecosystem was achieved when oat straw was buried - an additional $80 \mathrm{~kg} \mathrm{~N} \mathrm{ha}^{-1}$ compared with the treatment where straw was removed-but at a cost of impaired growth in the succeeding crop, possibly due to an intense $\mathrm{N}$ immobilization or to the development of allelochemicals. In this situation, only $17 \%$ of this extra $\mathrm{N}$ was unaccounted for (Fig. 2). If oat straw were surface applied, then unaccounted for $\mathrm{N}$ increased, but growth of the succeeding crop was no longer depressed. In this case, the extra annual input to the soil-plant system decreased from 80 to $52 \mathrm{~kg} \mathrm{~N} \mathrm{ha}^{-1}$. In the lupine-oat rotation, the contribution of straw conservation to the agroecosystem corresponded to an additional 61-63 kg N ha ${ }^{-1}$ and was not influenced by soil disturbance to any great extent.

\section{Conclusions}

Lupine residues decomposed faster, sustained a greater soil microbial activity, and enhanced plant growth in a subsequent crop by providing more $\mathrm{N}$ than oat residues did.
Buried residues from both crops decomposed faster than when applied on the soil surface, but soil disturbance had no effect on $\mathrm{N}$ recovery from lupine straw in the subsequent crop, although oat straw buried in the soil led to decreased growth of the following crop. Soil disturbance resulted in more residue $\mathrm{N}$ being retained by soil microorganisms as translated by microorganisms with higher dehydrogenase activity and greater numbers of culturable fungi. Although aboveground residues contributed to the total pool of $\mathrm{N}$ in the plant-soil system, a high proportion of the additional $\mathrm{N}$ introduced by straw was lost from the system. Both crops contributed to $\mathrm{N}$ conservation and cycling, but on a yearly basis, lupine contributed more $\mathrm{N}$ to the agroecosystem than oat. Lupine can contribute $73-95 \mathrm{~kg} \mathrm{~N} \mathrm{ha}^{-1}$ each year to the soil-plant system if harvest residues are returned to the soil.

Acknowledgements This study was funded by the Portuguese government and the European Union through project POCI/AGG/ $42616 / 2001$ from the FCT with funds from FEDER. We thank Paula Gonçalves Silva and Madalena Quelhas for technical assistance. We thank the Instituto Nacional de Investigação Agrária e Pescas for the use of the Pegões Experimental Station.

\section{References}

AOAC (1990) Official methods of analysis, 12th edn. Association of Official Agricultural Chemists, Washington, DC

Bayer C, Mielniczuk J, Amado TJC, Martin-Neto L, Fernandes SV (2000) Organic matter storage in a sandy clay loam Acrisol affected by tillage and cropping systems in southern Brazil. Soil Tillage Res 54:101-109

Bremner JM (1996) Total nitrogen. In: Sparks DL (ed) Methods of soil analysis. Part 3: chemical methods. Soil Science Society of America, Madison, Wisconsin, pp 1085-1121

Brooks PD, Stark JM, McInteer BB, Preston T (1989) Diffusion method to prepare soil extracts for automated nitrogen-15 analysis. Soil Sci Soc Am J 53:1707-1711

Campbell CA, Biederbeck VO, Zentner RP, Lafond GP (1991) Effect of crop rotation and cultural practices on soil organic matter, microbial biomass and respiration in a thin black chernozem. Can J Soil Sci 71:363-376

Chaves B, De Neve S, Hofman G, Boeckx P, Van Cleemput O (2004) Nitrogen mineralization of vegetable root residues and green manures as related to their (bio)chemical composition. Eur $\mathrm{J}$ Agron 21:161-170

Corbeels M, O'Connell AM, Grove TS, Mendham DS, Rance SJ (2003) Nitrogen release from eucalypt leaves and legume residues as influenced by their biochemical quality and degree of contact with soil. Plant Soil 250:15-28

Diekow J, Mielniczuk J, Knicker H, Bayer C, Dick DP, KögelKnabner I (2005) Soil C and N stocks as affected by cropping systems and nitrogen fertilisation in a southern Brazil Acrisol managed under no-tillage for 17 years. Soil Tillage Res 81:87-95

Doran JW (1987) Microbial biomass and mineralizable nitrogen distributions in no-tillage and plowed soils. Biol Fertil Soils 5:68-75

Franzluebbers AJ, Arshad MA, Ripmeester JA (1996) Alterations in canola residue composition during decomposition. Soil Biol Biochem 28:1289-1295 
Gil-Sotres F, Trasar-Cepeda C, Leirós MC, Seoane S (2005) Different approaches to evaluating soil quality using biochemical properties. Soil Biol Biochem 37:877-887

Goss MJ, de Varennes A (2002) Soil disturbance reduces the efficacy of mycorrhizal associations for early soybean growth and $\mathrm{N}_{2}$ fixation. Soil Biol Biochem 34:1167-1173

Heenan DP (1995) Effects of broad-leaf crops and their sowing time on subsequent wheat production. Field Crops Res 43:19-29

Heenan DP, Chan KY, Knight PG (2004) Long-term impact of rotation, tillage and stubble management on the loss of soil organic carbon and nitrogen from a Chromic Luvisol. Soil Tillage Res 76:59-68

Jensen ES (1997) Nitrogen immobilization and mineralization during initial decomposition of ${ }^{15} \mathrm{~N}$-labelled pea and barley residues. Biol Fertil Soils 24:39-44

Jensen CR, Joernsgaard B, Andersen MN, Christiansen JL, Mogensen VO, Friis P, Petersen CT (2004) The effects of lupins as compared with peas and oats on the yield of the subsequent winter barley crop. Eur J Agron 20:405-418

Jimenez MP, de la Horra AM, Pruzzo L, Palma RM (2002) Soil quality: a new index based on microbiological and biochemical parameters. Biol Fertil Soils 35:302-306

Kramer AW, Doane TA, Horwath WR, van Kessel C (2002) Short-term nitrogen-15 recovery vs. long-term total soil $\mathrm{N}$ gains in conventional and alternative cropping systems. Soil Biol Biochem 34:4350

Kumar K, Goh KM (2002) Management practices of antecedent leguminous and non-leguminous crop residues in relation to winter wheat yields, nitrogen uptake, soil nitrogen mineralization and simple nitrogen balance. Eur J Agron 16:295-308

López MV, Arrúe JL, Álvaro-Fuentes J, Moret D (2005) Dynamics of surface barley residues during fallow as affected by tillage and decomposition in semiarid Aragon (NE Spain). Eur J Agron $23: 26-36$
LQARS (2000) Manual de Fertilização das Culturas, MADRP/INIA, p 221

Mahmood T, Kaiser WM, Ali R, Ashrat M, Gulnaz A, Iqbal Z (2005) Ammonium versus nitrate nutrition of plants stimulates microbial activity in the rhizosphere. Plant Soil 277:233-243

Mayer J, Buegger F, Jensen ES, Schloter M, Heß J (2003) Residual nitrogen contribution from grain legumes to succeeding wheat and rape and related microbial process. Plant Soil 255:541554

Mubarak AR, Rosenani AB, Anuar AR, Zauyah DS (2003) Recovery of nitrogen from maize residue and inorganic fertilizer in a maize-groundnut rotation system in humid tropics of Malaysia. Commun Soil Sci Plant Anal 34:2375-2394

Pochon J, Tardieux P (1962) Techniques d' analyse en microbiologie du sol. La Tourelle, Saint Mandé (Seine), France, p 108

Sakonnakhon SPN, Toomsan B, Cadisch G, Baggs EM, Vityakon P, Limpinuntana V, Jogloy S, Patanothai A (2005) Dry season groundnut stover management practices determine nitrogen cycling efficiency and subsequent maize yields. Plant Soil 272:183-199

Shah Z, Shah SH, Peoples MB, Schwenke GD, Herridge DF (2003) Crop residue and fertiliser $\mathrm{N}$ effects on nitrogen fixation and yields of legume-cereal rotations and soil organic fertility. Field Crops Res 83:1-11

Rennie RJ, Dubetz S (1986) Nitrogen-15-determined nitrogen fixation in field-grown chickpea, lentil, fababean, and field pea. Agron J 72:654-660

Tabatabai MA (1994) Soil enzymes. In: Mickelson SH, Bigham JM (eds) Methods of soil analysis. Part 2. Microbiological and biochemical properties. Soil Science Society of America, Madison, WI, pp 775-833

Unkovich MJ, Pate JS, Armstrong EL, Sanford P (1995) Nitrogen economy of annual crop and pasture legumes in southwest Australia. Soil Biol Biochem 27:585-588 